\title{
PERAKITAN IKAN LELE (Clarias sp.) TRANSGENIK DENGAN TEKNIK ELEKTROPORASI SPERMA
}

\section{CONSTRUCTION OF TRANSGENIC CATFISH (Clarias sp.) USING SPERM ELECTROPHORATION TECHNIQUE}

\author{
Ibnu Dwi Buwono, Iskandar, M. Untung Kurnia Agung dan Ujang Subhan \\ Fakultas Perikanan Dan Ilmu Kelautan Universitas Padjadjaran \\ Jl. Raya Bandung Sumedang Km. 21 Jatinangor \\ Email : ibnudw1@yahoo.com
}

\section{INTISARI}

Aplikasi teknologi transfer gen melalui perantaraan sperma dimungkinkan untuk memperbaiki kualitas genetik ikan. Keberhasilan transfer gen hormon pertumbuhan (Growth Hormone $=\mathrm{GH}$ ) ikan budidaya melalui elektroporasi sperma dapat menghasilkan ikan transgenik. Pada penelitian ini dilakukan transfer konstruksi vektor ekspresi gen GH lele dumbo (pTarget-CMV-CgGH) ke sperma lele dumbo (strain mutiara) menggunakan kejut listrik $125 \mathrm{Vcm}-1$ dengan jumlah pulsa 3 dan 5 serta $50 \mathrm{Vcm}-1$ dengan jumlah pulsa 3 dan 5 . Konsentrasi vektor yang digunakan 60 $\mathrm{ng} / \mu \mathrm{L}$, lama kejutan 30 milidetik dan interval kejut 0,1 detik. Dari hasil elektroporasi sperma lele mutiara sebesar $125 \mathrm{Vcm}-1$ (jumlah pulsa 3 dan 5) serta $50 \mathrm{Vcm}-1$ (jumlah pulsa 3 dan 5) ini, terdeteksi fragmen berukuran 600 bp (gen GH lele dumbo) pada sperma dan fragmen 1000 bp (96 \% identik dengan GH Clarias gariepinus, no. aksesi AF416488.1) pada ikan umur 4 bulan menunjukkan keberhasilan transfer gen GH lele dumbo (GH eksogen) ke sperma lele mutiara. Rata-rata kelipatan tumbuh ikan lele mutiara transgenik umur 4 bulan (125 Vcm-1 dan 50 Vcm-1 dengan jumlah pulsa 3 dan 5) berturut- turut 3,53 kali; 3,05 kali; 2,75 kali dan 2,76 kali dari ukuran ikan non transgenik (over-ekspresi GH eksogen). GH eksogen terdeteksi pada ikan lele mutiara transgenik dan tidak terdeteksi pada ikan lele mutiara non transgenik (non elektroporasi). Ikan lele mutiara transgenik berhasil dirakit dengan menyisipkan gen GH lele dumbo menggunakan teknik elektroporasi sperma.

Kata kunci : elektroporasi, ikan lele, sperma, transgenik

\begin{abstract}
Applications of gene transfer technology through the intermediary of the sperm permit to improve the genetic quality of fish. The successful gene transfer of farmed fish growth hormone (GH = Growth Hormone) through sperm electroporation has produced transgenic fish. The objective of the research was to transfer African catfish $\mathrm{GH}$ gene expression vector construction (pTarget-CMV-CgGH) to the African catfish sperm (mutiara strain) using electric shock of $125 \mathrm{Vcm}-1$ and $50 \mathrm{Vcm}-1$ (with the number of pulses 3 and 5). Vector concentration used was $60 \mathrm{ng} / \mu \mathrm{L}, 30$ milliseconds pulse length and pulse interval of 0.1 seconds. After the electroporation of mutiara catfish sperm of $125 \mathrm{Vcm}-1$ and $50 \mathrm{Vcm}-1$ (both the number of pulses 3 and 5), the $600 \mathrm{bp}$ fragment size (African catfish GH gene) of sperm and 1000 bp fragment size (96\% identical to GH Clarias gariepinus, no. accession AF416488.1) of fish 4 months aged were observed. This showed that the African catfish GH (exogenous GH) gene were transferred successfully to mutiara catfish sperm. On average multiples grow transgenic mutiara catfish age of 4 months (125 Vcm-1 and 50 Vcm-1 with the number of pulses 3 and 5 ) respectively 3.53 times; 3.05 times; 2.75 times and 2.76 times the size of non-transgenic fish (over-expression of exogenous GH). Exogenous GH detected in transgenic mutiara catfish as well not detected in non transgenic catfish (non electroporation). Catfish mutiara transgenic successfully assembled by inserting African catfish GH genes using sperm electroporation technique .
\end{abstract}

Keywords : catfish, electroporation, sperm, transgenic

\section{PENDAHULUAN}

Perbaikan genetika pertumbuhan ikan lele (Clarias sp.) melalui program pemuliaan (selective breeding) dipandang kurang menguntungkan, karena memerlukan waktu lama dan sulitnya memisahkan trait menguntungkan dari ikan yang diseleksi (Pandian \& Venogupal, 2005). Aplikasi teknologi transfer gen dewasa ini dapat mengatasi kendala tersebut, karena dimungkinkan memasukkan gen asing ke dalam 
genom telur ikan untuk perbaikan genetik ikan yang dibudidayakan ke arah sifat menguntungkan (Fletcher et al., 2002). Integrasi antara gen asing yang ditransfer (transgen) ke dalam genom ikan inang diharapkan memperbaiki ekspresi gen inang (over-ekspresi) yang diwariskan kepada keturunannya (Hackett, 1993).

Dua teknik transfer gen yang umumnya diaplikasikan pada genom ikan adalah metode mikroinjeksi telur dan elektroporasi pada sperma ikan (Iyengar \& Maclean, 1995). Teknik mikroinjeksi telur memerlukan prosedur yang rumit dan teknik tinggi, mengingat nukleus telur ikan diselubungi kuning telur yang menyulitkan menginjeksikan DNA asing melalui korion telur menyebabkan penggunaan metode tersebut kurang menguntungkan. Sebaliknya metode elektroporasi sperma ikan lebih simpel dan merupakan metode massal penyisipan gen asing ke dalam genom sperma yang selanjutnya ditransmisikan kepada keturunannya setelah pembuahan dengan telur ikan (Muller et al., 1993; Spadafora, 2008). Berdasar hal ini, sperma bertindak sebagai pembawa (carrier) gen-gen asing yang diintroduksikan ke dalam telur ikan, dipandang lebih efisien dibandingkan mikroinjeksi.

Secara alami, hewan akuatik (termasuk ikan) memproduksi sejumlah besar sel sperma yang menguntungkan bagi aplikasi transfer gen yang diperantarai sperma (SMGT $=$ Sperm Mediated Gene Transfer) (Collares et al., 2010). Transfer gen hormon pertumbuhan ( $\mathrm{GH}=$ Growth Hormone) ikan rainbow trout melalui teknik SMGT pada sperma ikan mas India (Labeo rohita) yang kemudian difertilisasi pada telur ikan tersebut menghasilkan transmisi transgen pada larva ikan tersebut sebesar 25\%. Keberhasilan transfer gen asing menggunakan perantaraan sperma sebelum fertilisasi juga ditunjukkan pada ikan ayu (Plecoglossus altivelis) sebesar 55 \% (Zhang et al., 1990), pada ikan mud loach (Misgurnus mizolepis) (Tsai et al., 1997) dan pada ikan zebrafish sebesar 80\% (Powers et al., 1992). Sementara transfer gen hormon pertumbuhan pada stripped catfish (Pangasionodon hypopthalmus) sebesar 85,71\% (Dewi et al., 2010b).

Penggunaan ikan dalam penelitian transgenesis lebih menguntungkan, dibandingkan mamalia, karena memproduksi gamet berlimpah. Penanganan gamet ikan lebih mudah karena fertilisasinya eksternal dan telur ikan lebih totipoten dibanding mamalia (Pandian \& Venogupal, 2005). Proses transfer gen ini memerlukan metode khusus untuk mengirimkan transgen ke dalam genom ikan yang akan diperbaiki fenotipnya, salah satunya menggunakan teknik elektroporasi sperma.

Elektroporasi merupakan metode transfer gen yang sesuai untuk ikan, karena sistem transfer tersebut bersifat massal, mengingat sperma dalam jumlah besar dapat diinsersi transgen secara serempak dengan teknik SMGT. Transgen yang terkandung dalam genom sperma akan berintegrasi dengan genom telur ketika terjadi fertilisasi. Hal ini memungkinkan adanya rekombinasi gen pada genom embrio telur, sehingga diharapkan larva yang menetas dapat mengekspresikan transgen tersebut (Caelers et al., 2005). Perlakuan elektroporasi merenggangkan sel sperma dengan intensitas medan listrik tinggi yang secara temporer mendestabilisasi membran sel. Selama periode tersebut, membran sangat permeabel dengan molekul-molekul eksogen (DNA atau RNA) yang terdapat di sekitar media sel. DNA kemudian bergerak ke dalam sel (proses internalisasi) melalui lubang permeabel ini. Ketika medan listrik berhenti (turn off), lubang dalam membran menutup, DNA eksogen masuk ke dalam sel (Spadafora, 2008).

Ekspresi transgen yang disisipkan ke dalam genom sperma ikan diatur oleh promoter sebagai elemen regulatorik transkripsi untuk ekspresi gen (Nam et al., 2001). Dalam upaya mendorong ekspresi transgen dengan teknik SMGT, diperlukan promoter yang kompatibel dengan gen yang disisipkan (Alimuddin et al., 2007). Promoter $\beta$-aktin merupakan promoter yang mampu mendorong ekspresi transgen pada ikan transgenik (Noh et al., 2003).

Selain penggunaan promoter $\beta$-aktin, promoter lain yang potensial mendorong ekspresi transgen adalah promoter yang berasal dari RSV (Rous sarcoma virus) dan CMV (Cytomegalovirus enhancer) serta SV 40 (simian virus 40 enhancer). Promoter $\mathrm{CMV}$ telah digunakan dalam konstruksi transgen pCMV-rGH-IRES2-EGFP dengan teknik SMGT pada ikan mas India, rohu (Labeo rohita) dengan ekspresi gen Growth Hormone (GH) ikan tersebut, yang menghasilkan peningkatan $2-3$ kali pertumbuhannya dibanding kontrol (non transgenik) (Pandian \& Venogupal, 2005). Penggunaan promoter CMV ini juga telah berhasil mendorong ekspresi transgen dalam embrio African catfish (Clarias gariepinus), zebrafish dan rosy barb berkisar 25 - 50\% (Muller et al., 1993). Konstruksi vektor ekspresi rekombinan tersebut adalah pCMV/lac Z yang mengandung promoter CMV IE serta poliadenilasi SV 40 yang digunakan pada konsentrasi $50 \mu \mathrm{g} / \mathrm{ml}$.

Keberhasilan transfer gen pada larva dideteksi menggunakan PCR untuk memastikan transmisi transgen pada generasi awal (Fo). Perkawinan antara generasi Fo ini menghasilkan keturunan F1 yang dideteksi keberadaan transgen pada individu F1 untuk meyakinkan transmisi transgen dari generasi Fo ke generasi F1. Penelitian transgenesis menggunakan SMGT di Indonesia telah berhasil dilakukan yaitu pada ikan kerapu bebek (Cromileptes altivelis) transgenik yang mengandung konstruksi gen pktBP-ktGH dengan konsentrasi $10 \mu \mathrm{g} / \mathrm{ml}$ dengan kondisi elektroporasi sperma yaitu panjang pulsa $50 \mathrm{~V} / \mathrm{cm}$, lama elektroporasi 30 milidetik, jumlah pulsa 5 dan interval pulsa 0,1 detik (Subyakto et al., 2011). Transgenesis juga telah berhasil dilakukan pada ikan lele (Clarias sp.) dengan gen $\mathrm{GH}$ ikan nila (tiGH) menggunakan elektroporasi sperma, dengan kondisi optimal yaitu kuat medan listrik $125 \mathrm{~V} /$ $\mathrm{cm}$, panjang kejutan (pulse length) 30 milidetik, jumlah 
kejutan (number of pulse) 5 kali serta interval kejutan (pulse interval) 0,1 detik. Efisiensi transfer konstruksi mBP-TiGH pada ikan lele tersebut sebesar 93\% untuk konsentrasi DNA $80 \mu \mathrm{g} / \mathrm{ml}$ (Gusrina et al., 2009). Hasil penelitian Dewi dkk. (2010b) juga berhasil menstransfer gen GH patin siam yang terkandung pada konstruksi pCcBA-phGH pada ikan patin siam (Pangasionodon hypophthalmus) dengan efisiensi transfer sebesar 85,71\% untuk konsentrasi DNA plasmid $90 \mu \mathrm{g} / \mathrm{ml}$. Kondisi optimal untuk elektroporasi tersebut yaitu panjang kejutan 30 milidetik, interval kejutan 0,1 detik, kuat medan listrik (electric field strength) $125 \mathrm{Vcm}-1$.

Berpedoman dari latar belakang yang telah diuraikan di atas, konstruksi vektor ekspresi gen GH lele dumbo yang akan ditransfer ke sperma ikan lele dumbo (mutiara) dan lele lokal dengan teknik SMGT adalah pTargetCMV-GH lele dumbo (mengandung promoter CMV ke dalam genom sperma ikan lele dumbo (strain Mutiara). Tujuan utama yang ingin dicapai dalam penelitian ini diperoleh ikan lele transgenik yang membawa sisipan gen hormon pertumbuhan ikan lele dumbo sebagai upaya perbaikan sifat pertumbuhan ikan lele dumbo yang menurun dewasa ini.

\section{MATERI DAN METODE}

\section{Perakitan Konstruksi Vektor Ekspresi pTarget-} promoter CMV-GH Lele Dumbo (CgGH)

Vektor pTargetTM berasal dari vektor pCI-neo dan mengandung elemen-elemen identik pengaturan ekspresi pada gen yang dikloning. Ekspresi dari gen yang diinsersikan dalam vektor pTARGETTM diatur oleh promoter/enhancer human cytomegalovirus (CMV), suatu daerah regulatorik transkripsi kuat yang aktif pada berbagai tipe sel (Promega, 2008).

Kebanyakan intron chimeric yang terletak pada downstream CMV berfungsi meningkatkan ekspresi kebanyakan gen yang diinsersikan. Vektor ekspresi ini (Gambar 1) juga mengandung downstream sinyal poliadenilasi akhir simian virus 40 (SV 40) pada tapak kloning. Sinyal poliadenilasi akhir SV 40 secara ekstrem efisien ketika menginduksi transkrip-transkrip RNA pada poliadenilasi yang diperlukan untuk level tinggi ekspresi.

Konstruksi gen yang digunakan dalam elektroporasi sperma ikan lele mutiara dan lokal yaitu pTARGET-CMVCgGH (dengan promoter Cytomegalovirus dan sisipan hormon pertumbuhan lele dumbo/Clarias gariepinus Growth Hormone $=\mathrm{CgGH}$ ). Konstruksi pTARGET-CMV$\mathrm{CgGH}$ yang telah berhasil dibuat disajikan pada Gambar.

\section{Isolasi Vektor Rekombinan (pTarget-CMV-GH lele dumbo) dan Analisis Sisipan Gen GH Lele dumbo}

Setelah dilakukan panen sel kompeten Escherichia coli JM 109 pembawa vektor rekombinan, kemudian dilanjutkan dengan isolasi vektor rekombinan menggunakan kit high speed mini plasmid (Geneaid) mengikuti protokol dari kit tersebut. Deteksi sisipan gen

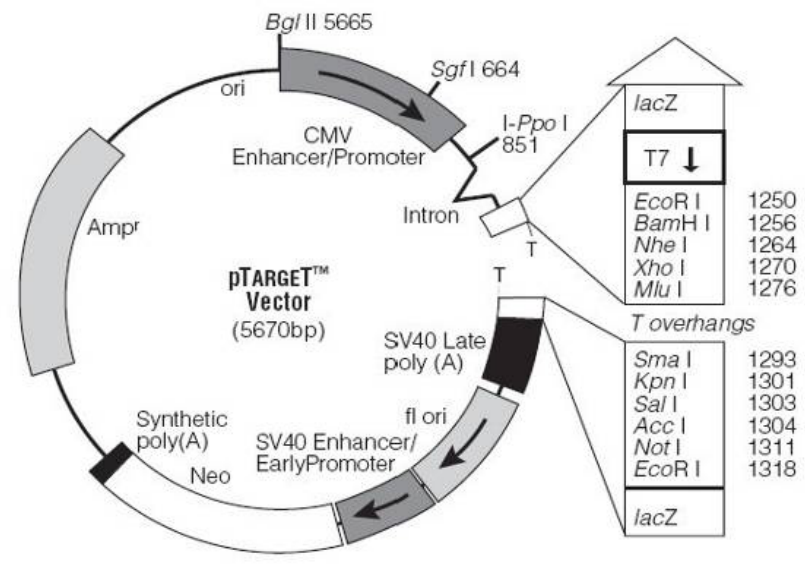

Gambar 1. Vektor Ekspresi pTargetTM (5670 bp) (Promega, 2008)

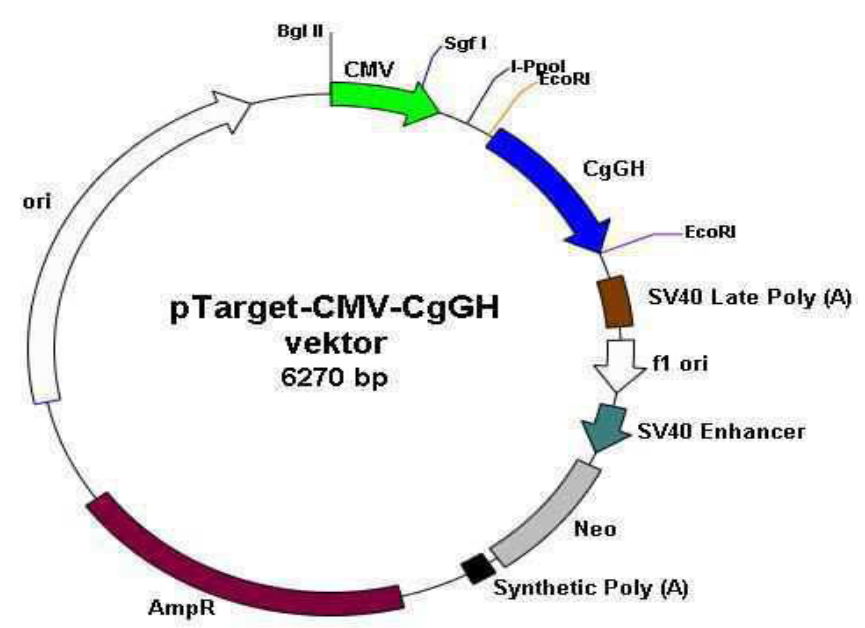

Gambar 2. Konstruksi pTargetTM-CMV-CgGH (6.270 bp) (Promega, 2008)

GH lele dumbo yang terinsersi dalam konstruksi pTargetCMV-GH lele dumbo) menggunakan PCR dengan primer $\mathrm{Cg}-\mathrm{F}$ dan $\mathrm{Cg}-\mathrm{R}$. Komposisi campuran reaksi PCR sebagai berikut : Go Taq Green master mix (Promega) $(12,5 \mu \mathrm{L})$; primer $\mathrm{Cg}-\mathrm{F}(10 \mathrm{pmol})(1,25 \mu \mathrm{L})$; primer $\mathrm{Cg}-\mathrm{R}(10 \mathrm{pmol})$ $(1,25 \mu \mathrm{L})$; DNA vektor (pTarget-CMV-CgGH) $(2,5 \mu \mathrm{L})$ ; Sterile Deinozed Water (SDW) $(7,5 \mu \mathrm{L})$ dengan total volume campuran $25 \mu \mathrm{L}$.

Program amplifikasi yang digunakan sebagai berikut: pra denaturasi pada suhu $95^{\circ} \mathrm{C}$ (selama 5 menit), denaturasi pada suhu $94^{\circ} \mathrm{C}$ (selama 30 detik), annealing pada suhu $55^{\circ} \mathrm{C}$ (selama 30 detik), ekstensi pada suhu $72^{\circ} \mathrm{C}$ (selama 2 menit) dan ekstensi akhir pada suhu $720 \mathrm{C}$ (selama 7 menit). Jumlah siklus amplifikasi sebanyak 36 kali dan menggunakan elektroforesis gel agarose $1 \%$.

\section{Pengukuran Konsentrasi DNA Vektor Rekombinan (pTarget-CMV-CgGH)}

Konsentrasi DNA vektor rekombinan perlu diukur, mengingat, kadar optimum konsentrasi yang diperlukan untuk elektroporasi ke sperma ikan berkisar antara 60 - $100 \mu \mathrm{g} / \mathrm{mL}$ (6o - $100 \mathrm{ng} / \mu \mathrm{L})$. Pengukuran konsentrasi 


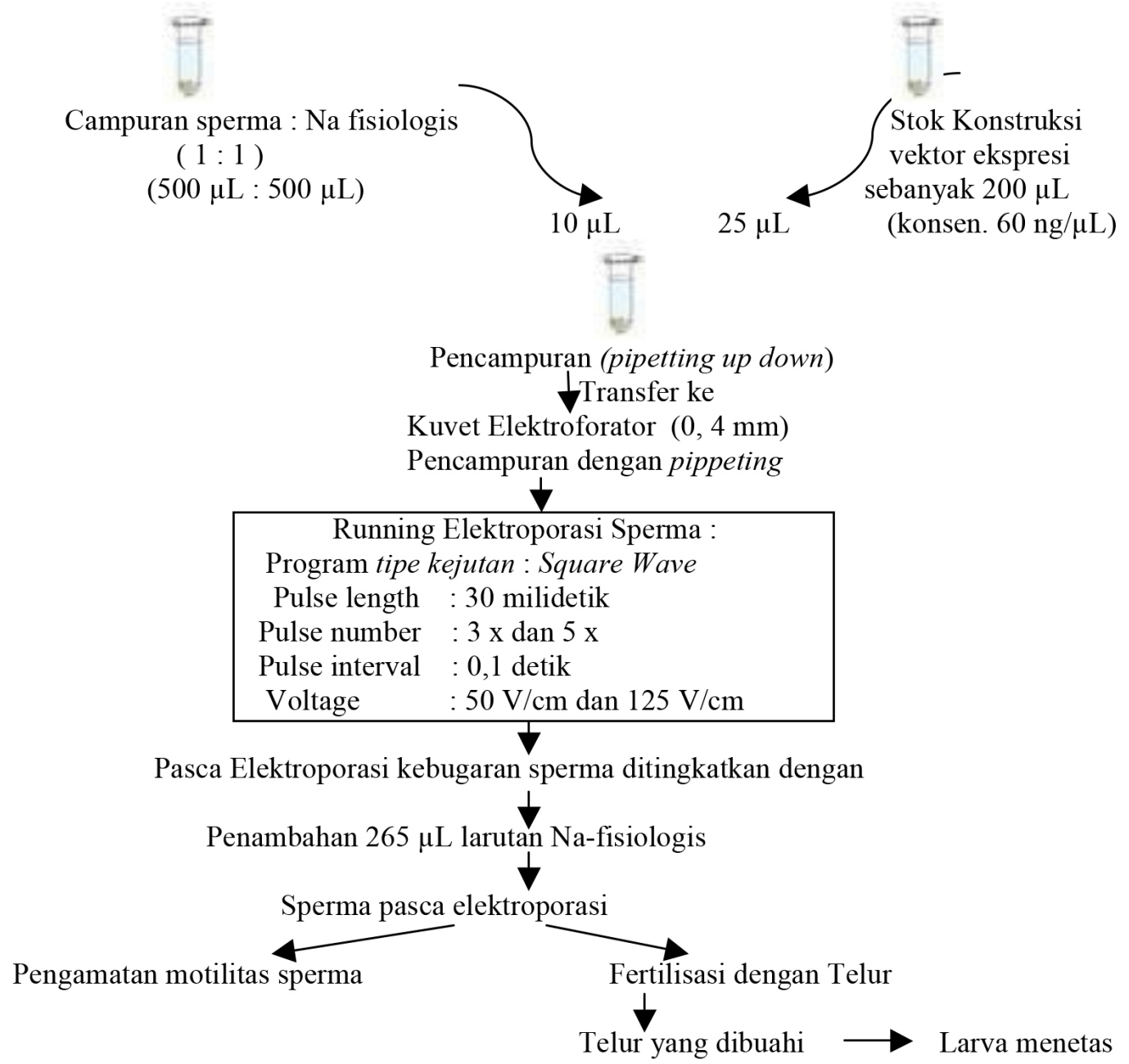

Gambar 3. Alur Kerja Elektroporasi Sperma

sampel vektor pTarget-CMV-CgGH menggunakan NanoDROP 2000 Thermo Scientific.

\section{Perlakuan Kejut Listrik Untuk Konstruksi Gen yang Ditransfer Dalam Proses Elektroporasi}

Tujuan transfer gen GH lele dumbo yang tersisip dalam vektor ekspresi untuk meningkatkan pertumbuhan lele mutiara atau lele lokal lebih tinggi dari pada lele non transgenik (non elektroporasi). Khusus untuk lele dumbo yang dipergunakan dalam perlakuan elektroporasi adalah lele mutiara berasal dari Balai Penelitian Pemuliaan Ikan (BPPI) Sukamandi yang merupakan hasil perakitan seleksi individu dari populasi sintetis yang dibentuk dari populasi ikan lele Paiton, ikan lele Sangkuriang, ikan lele Dumbo Lokal dan ikan lele Mesir (Iswanto et al., 2014). Rancangan elektroporasi yang dilakukan mengikuti petunjuk teknis yang disarankan dalam gene pulser II BioRad, hanya dibedakan atas 2 penggunaan voltase (125 Vcm-1 dan $50 \mathrm{Vcm}-1$ ) dengan jumlah pulsa 3 dan 5 kali yang diaplikasikan baik pada sperma lele dumbo (mutiara) dan lele lokal.

Perlakuan kontrol yang digunakan adalah sperma ikan tanpa elektroporasi (non vektor) untuk melihat perbedaan pertumbuhan ikan transgenik dengan ikan yang normal (tanpa vektor atau mon transgenik) dan mendeteksi keberadaan gen hormon pertumbuhan lele dumbo $(\mathrm{CgGH})$ yang disisipkan ke sperma lele mutiara dan lele lokal. Alur kerja elektroporasi sperma dapat dicermati pada Gambar 3 .

\section{Transfer Vektor Ekspresi Rekombinan ke DNA Sperma Lele dengan Elektroporasi}

Penggunaan volume larutan DNA vektor rekombinan (pTARGETTM-CMV-CgGH) untuk ditransferkan ke sperma lele mutiara (Clarias sp.) dan lele lokal ( $C$. batrachus) masing-masing sebesar $60 \mathrm{ng} / \mu \mathrm{l}$ (Dewi dkk. 2010b). Sebelum pencampuran dengan DNA vektor rekombinan, sperma kedua jenis lele dikoleksi terlebih dahulu di dalam cawan petri yang hanya dipergunakan sebesar 0,5 ml. Sperma lele diperoleh dengan menseksio bagian abdomen induk jantan untuk diambil testisnya, setelah dilakukan penyuntikan dengan hormon ovaprim dengan dosis $0,5 \mathrm{ml} / \mathrm{kg}$ berat tubuh induk serta dilakukan setelah 12 jam dari penyuntikan tersebut. Sperma yang telah tertampung tersebut (0,5 ml masing-masing cawan petri) kemudian diencerkan dengan larutan garam fisiologis (larutan isotonik) untuk mempertahankan motilitas sperma dengan rasio 0,5 $\mathrm{ml}$ sperma dan 0,5 


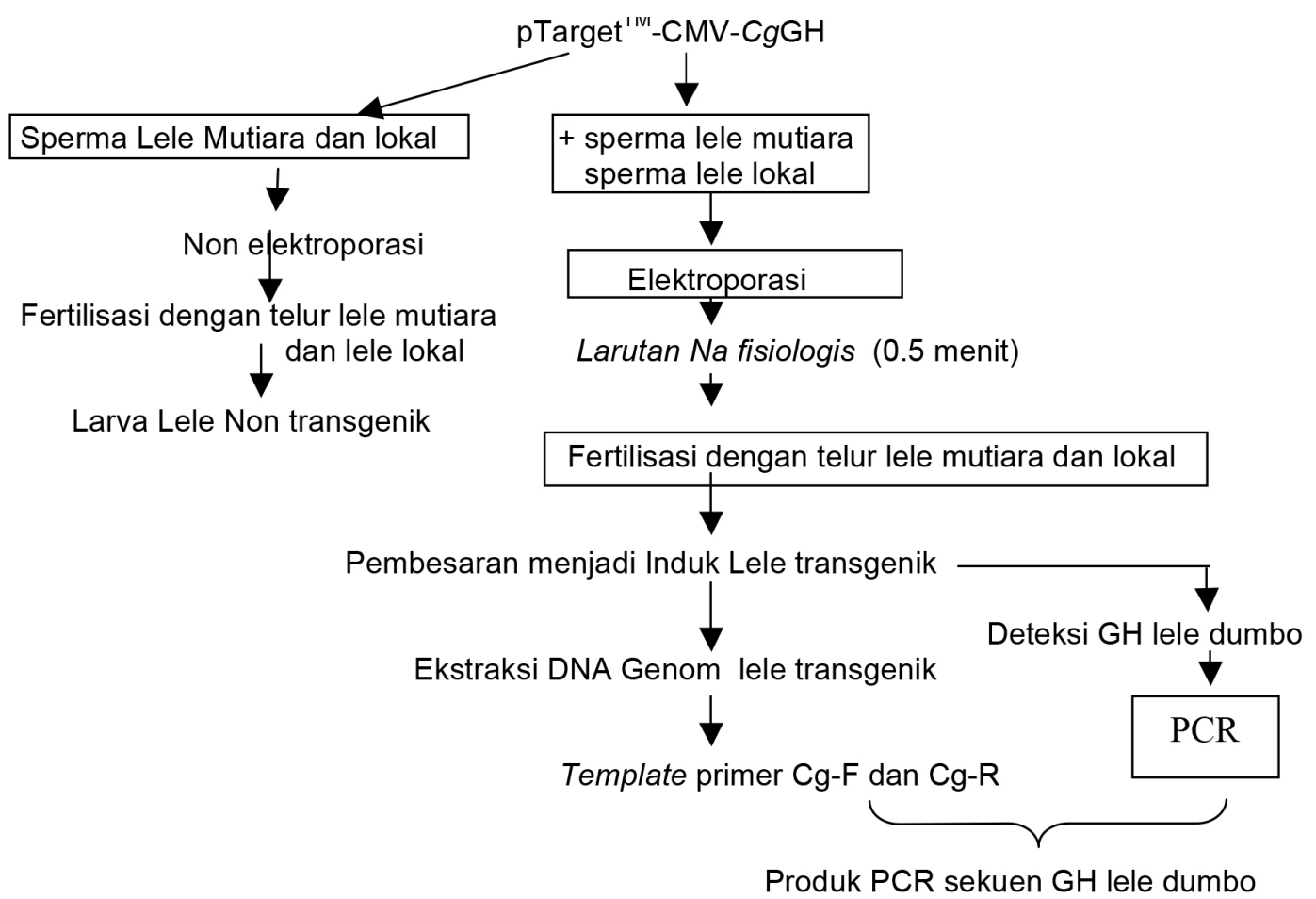

Gambar 4. Skema Pengerjaan Tahap Transfer Gen dengan ElektroporasiSperma Lele Mutiara maupun Lokal dan Deteksi GH Lele Dumbo

ml larutan Na-fisiologis $(1: 1)$.

Bersamaan dengan hal itu, juga dilakukan stripping pada induk betina lele mutiara dan lokal, setelah disuntik dengan hormon ovaprim dosis $0.5 \mathrm{ml} / \mathrm{kg}$ berat tubuh dan distripping 8 - 10 jam setelah penyuntikan untuk mengovulasikan telur. Telur kemudian ditampung dalam cawan plastik (kondisi kering tanpa air). Selanjutnya dilakukan proses elektroporasi dengan mencampur sperma dan DNA vektor ke dalam kuvet mesin elektroporasi gene pulser II (BioRad) dengan tipe kejutan square wave shock, yang diprogram yaitu $50 \mathrm{Vcm}-1$ dan $125 \mathrm{Vcm}-1$; lama kejutan 30 milidetik(ms); interval kejutan o,1detik serta jumlah pulsa 3 dan 5 kali. Setelah selesai kejutan, dengan segera sperma-sperma yang telah dielektroporasi ditambah larutan garam fisiologis (260 $\mu \mathrm{L})$ kemudian dicampur dengan telur lele mutiara yang sedikit demi sedikit ditambahkan air mineral, dan diatur suhu air pembuahan sekitar $26-27^{\circ} \mathrm{C}$ dan kemudian diinkubasi hingga larva menetas. DNA sperma dan larva lele mutiara maupun lele lokal diisolasi untuk deteksi keberadaan transgen tersebut. Skema deteksi CgGH pada sperma dan ikan lele pasca elektroporasi disajikan dalam Gambar 4.

Berdasar skema pengerjaan transfer gen hormon pertumbuhan lele dumbo ke sperma lele mutiara dan lokal yang dilanjutkan dengan fertilisasi dengan telur kedua jenis lele tersebut (Gambar 4), hanya diperoleh larva lele mutiara transgenik, oleh karena pada larva lele lokal pasca elektroporasi mortalitasnya tinggi, sehingga larva lele mutiara transgenik yang dipelihara sampai menjadi induk dan karakter pertumbuhannya dibandingkan dengan ikan lele mutiara non transgenik.
Keberadaan gen hormon pertumbuhan lele dumbo dalam genom ikan lele mutiara transgenik (transgen) dideteksi menggunakan PCR dengan primer $\mathrm{Cg}-\mathrm{F}$ dan $\mathrm{Cg}-\mathrm{R}$.

\section{HASIL}

\section{Sisipan Gen GH Lele Dumbo Dalam Vektor Ekspre- si Rekombinan}

Hasil visualisasi produk PCR, menunjukkan keberadaan insert (sisipan) gen $\mathrm{GH}$ lele dumbo $(\mathrm{CgGH})$ berukuran sekitar 600 bp baik pada sampel pTarget-CMV-CgGH1 dan pTarget-CMV-CgGH2. Selain keberadaan sisipan $\mathrm{GH}$, juga terdeteksi vektor ekspresi rekombinan pTargetCMV-CgGH dengan ukuran fragmen sekitar $6270 \mathrm{bp}$ (Gambar 5).

Fragmen gen GH lele dumbo yang berukuran sekitar 600 bp terdeteksi menggunakan primer $\mathrm{Cg}-\mathrm{F}$ dan $\mathrm{Cg}-\mathrm{R}$ dalam konstruksi vektor pTarget-CMV-GH lele dumbo (Gambar 5), hal ini menunjukkan bahwa hasil isolasi vektor rekombinan dari sel kompeten JM109 merupakan konstruksi gen yang diharapkan dan dapat digunakan untuk tujuan elektroporasi ke sperma lele mutiara dalam upaya membuat ikan lele mutiara transgenik.

Konfirmasi keberadaan vektor ekspresi pTarget-CMV yang berukuran $5670 \mathrm{bp}$ (Promega 2008) yang bergabung dengan GH lele dumbo (6oo bp), sehingga ukuran vektor rekombinan (pTarget-CMV-GH) tersebut menjadi 6270 bp terdeteksi dalam elektroforegram yang disajikan pada Gambar 5. Fragmen ukuran 6270 bp tersebut terletak di antara ukuran 6000 bp dan 8000 bp, sehingga baik pada sampel DNA vektor pTarget-CMV-CgGH1 (GH lele dumbo yang diisolasi dari RNA hipofisa lele ke-1) dan 


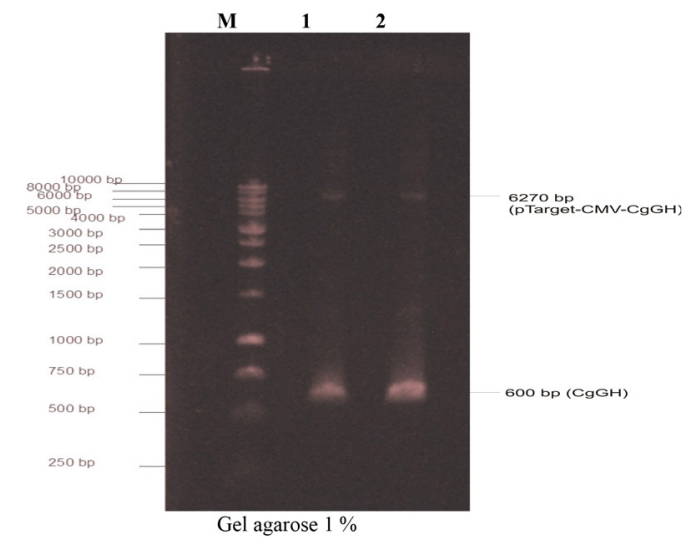

Gambar 5. Verifikasi GH Lele Dumbo pada pTarget-CMV-CgGH Keterangan :

$\mathrm{M}=$ marker DNA ladder $1 \mathrm{~kb}$

$1=$ DNA vektor pTarget-CMV-CgGH1

2 = DNA vektor pTarget-CMV-CgGH2

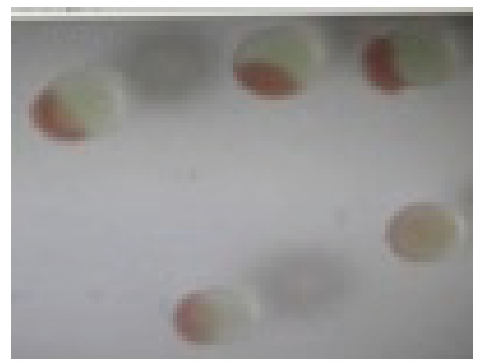

(A)

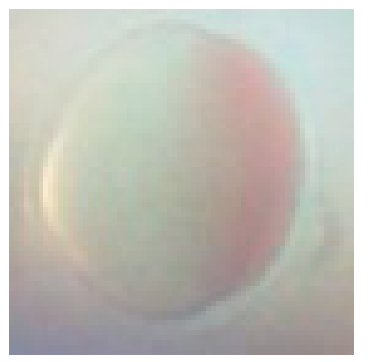

(B)
Gambar 6. Telur Lele Lokal yang Dibuahi Pasca Elektroporasi (A) dan Telur Lele Mutiara yang Dibuahi Pasca Elektroporasi (B)

pTarget-CMV-CgGH2 (GH lele dumbo yang diisolasi dari RNA hipofisa lele ke-2), keberadaan fragmen GH lele dumbo sebagai sisipan telah terverifikasi dengan tepat.

\section{Hasil Elektroporasi Sperma Lele Mutiara dan Lo- kal serta Telur yang Dibuahi (Transfer Gen Hor- mon Pertumbuhan (GH) Lele Dumbo)}

Proses kejutan listrik (elektroporasi) pada sperma lele mutiara dan lokal dilakukan di Lab. Genetika Pemuliaan Ikan BPPI Sukamandi, dengan terlebih dahulu mengkoleksi sperma ikan tersebut, dan kemudian dilakukan pencampuran sperma lele lokal dengan konstruksi gen (pTarget-CMV-CgGH). Kejut listrik sperma yang telah ditambah dengan konstruksi gen tersebut dengan takaran yang telah dijelaskan pada Gambar 4 dilakukan di dalam kuvet elektroforator dengan profil kejutan yang ditampilkan pada layar display elektroforator.

Berdasarkan hasil pengamatan mikroskop digital khususnya terhadap sperma lele mutiara dan lokal yang telah dielektroporasi masih menunjukkan motilitas yang cukup tinggi, walaupun gerak sperma sedikit mengalami penurunan. Hasil fertilisasi antara kedua jenis sperma lele pasca elektroporasi dengan telur kedua jenis lele tersebut menunjukkan proses pembuahan yang normal. Hal ini diindikasikan dengan berkembangnya telur lele lokal yang dibuahi hingga menetas menjadi larva. Demikian pula sebaliknya dengan telur lele mutiara menunjukkan hal yang sama (Gambar 6A dan 6B).

Larva lele mutiara yang telah menetas kemudian dipelihara lebih lanjut dan mulai hari ketiga hingga 10 hari pemeliharaan, larva lele diberi pakan berupa nauplii artemia, dan diamati perkembangannya. Hari kelima setelah menetas, larva ikan berkembang dan tumbuh menyerupai ikan lele dewasa, dan suka berada di dasar wadah pemeliharaan. Khususnya pada larva lele lokal (perlakuan elektroporasi $50 \mathrm{Vcm}-1$ dan $125 \mathrm{Vcm}-1$ dengan jumlah pulsa 3 dan 5), banyak terjadi mortalitas larva ikan dibanding pada larva lele mutiara. Sebaliknya dengan kondisi yang terdapat pada wadah pemeliharaan larva lele mutiara, yang sedikit mortalitasnya. Dengan demikian, hanya larva-larva lele mutiara transgenik yang diperoleh dan dibesarkan lebih lanjut menjadi calon induk Fo. Pada wadah pemeliharaan elektroporasi 50 Vcm-1, jumlah pulsa 3 pada lele mutiara, terdapat 3 ekor larva ikan yang pertumbuhannya lebih besar dari pada yang lainnya, dan diperkirakan merupakan larva lele mutiara transgenik. Pada perlakuan $125 \mathrm{Vcm}-1$, jumlah pulsa 3 maupun jumlah pulsa 5 pada larva lele mutiara terdapat larva yang berukuran lebih besar dibandingkan larva lele mutiara non transgenik.

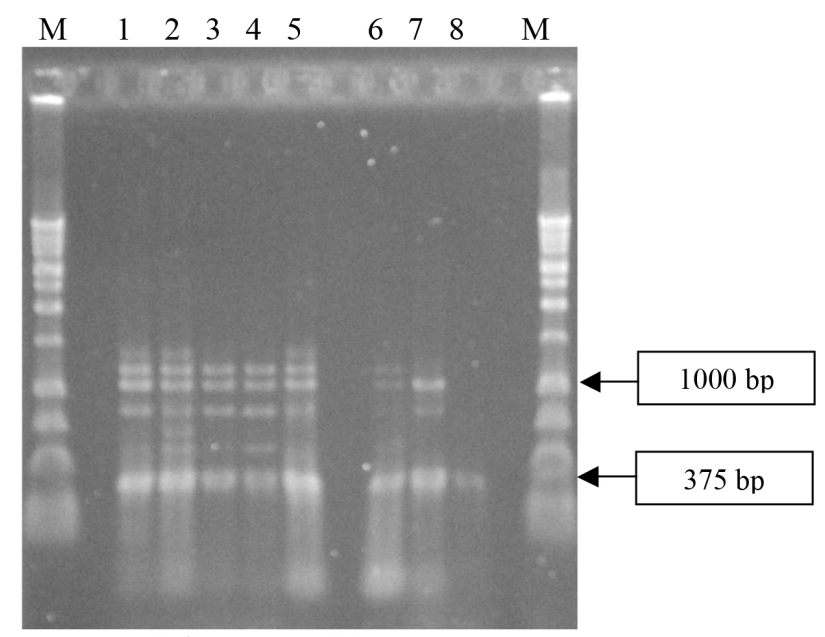

Gel agarosa $1 \%$

Gambar 7. Deteksi GH Eksogen pada Ikan Lele Transgenik dan Non Transgenik

$\mathrm{M}=$ marker DNA ladder $1 \mathrm{~kb}$

1 = elektroporasi $125 \mathrm{~V} / \mathrm{cm}$-pulsa 3 (ikan no.1)

2 = elektroporasi $125 \mathrm{~V} / \mathrm{cm}$-pulsa 3 (ikan no.2)

3 = elektroporasi $125 \mathrm{~V} / \mathrm{cm}$-pulsa 3 (ikan no.3)

4 = elektroporasi $125 \mathrm{~V} / \mathrm{cm}$-pulsa 5 (ikan no.4)

5 = elektroporasi $125 \mathrm{~V} / \mathrm{cm}$-pulsa 5 (ikan no.5)

6 = elektroporasi 5oV/cm-pulsa 3 (ikan no.6)

7 = elektroporasi 5oV/cm-pulsa 5 (ikan no.7)

$8=$ non elektroporasi atau non transgenik (NT)

Deteksi keberhasilan transfer gen hormon pertumbuhan lele dumbo (GH eksogen) yang terintegrasi dalam 
genom ikan lele mutiara transgenik (hasil elektroporasi) diperlukan untuk memastikan bahwa peningkatan pertumbuhan ikan transgenik dikarenakan over ekspresi GH eksogen tersebut. Hasil PCR menggunakan primer $\mathrm{Cg}-\mathrm{F}$ dan $\mathrm{Cg}-\mathrm{R}$ pada sampel ikan transgenik (lele mutiara hasil elektroporasi) dan ikan non transgenik (lele mutiara non elektroporasi) menunjukkan perbedaan fragmen DNA yang terkopi (Gambar 7). Pada ikan transgenik (sumur ke-1 sampai dengan ke-7 Gambar 7) terdapat fragmen $\mathrm{GH}$ eksogen (fragmen berukuran $1000 \mathrm{bp}$ ) dan ikan non transgenik (sumur ke-8 Gambar 7) tidak terdapat fragmen $\mathrm{GH}$ eksogen. Hal ini membuktikan bahwa genom ikan transgenik mengandung sisipan GH eksogen, sedangkan ikan non transgenik tidak mengandung sisipan GH eksogen yang menunjukkan keberhasilan transfer GH lele dumbo ke dalam ikan lele mutiara.

\section{PEMBAHASAN}

Konstruksi gen (pTarget-CMV-GH lele dumbo) diperbanyak melalui kultur sel kompeten Esherichia coli JM 109 (Promega) untuk mendapatkan vektor rekombinan yang ditransfer ke sperma lele dumbo menggunakan elektroforator. Keberadaan sisipan gen hormon pertumbuhan ini ( $\mathrm{GH}$ lele dumbo) perlu diverifikasi kembali pada vektor rekombinan tersebut untuk memastikan bahwa sisipan gen GH telah terkandung dalam konstruksi gen yang ditransfer. Hasil yang ditunjukkan dalam Gambar 5 membuktikan bahwa vektor rekombinan mengandung sisipan gen $\mathrm{GH}$ lele dumbo. Ukuran fragmen DNA vektor rekombinan yang mengandung sisipan gen GH lele dumbo sebesar 6270 bp, dan fragmen DNA GH lele dumbo sebesar 600 bp (Gambar 5). Kedua fragmen DNA ini terdeteksi berdasarkan elektroforesis gel agarosa $1 \%$ yang disajikan dalam Gambar 5 tersebut, sehingga hasil perbanyakan vektor rekombinan dalam kultur sel kompeten E. coli mengandung sisipan gen GH lele dumbo dan layak digunakan untuk transfer gen ke sperma lele mutiara.

Elektroporasi dapat menjadi metode massal transfer gen melalui perantaraan sperma untuk produksi ikan transgenik, relatif mudah dikuasai penanganannya, mengingat sperma pasca elektroporasi dalam jumlah banyak dapat difertilisasi kepada telur guna meningkatkan efisiensi gen yang ditransfer (Tsai et al., 1997). Transfer gen pada ikan melalui sperma yang dielektroporasi tergantung pada level voltase dan konsentrasi DNA vektor selama elektroporasi (Tsai, 2000). Integrasi DNA yang ditransfer (transgen) ke dalam sperma tergantung pada tegangan listrik (Vcm-1), jumlah kejutan (pulse numbers) dan konsentrasi DNA (Faqih, 2011). Hasil penelitian elektroporasi pada sperma ikan lele dumbo sebagai media transfer gen terbaik dilakukan pada tegangan $40 \mathrm{Vcm}-$ 1 (Faqih, 2011). Pada penelitian ini, konsentrasi DNA transgen yang digunakan untuk elektroporasi sperma ikan lele mutiara dan lele lokal sebesar $60 \mu \mathrm{g} / \mathrm{mL}$ atau setara dengan $60 \mathrm{ng} / \mu \mathrm{L}$. Penggunaan konsentrasi DNA transgen ini tidak jauh berbeda dengan yang digunakan pada ikan lele Amerika (Rhamdia quelen) sebesar $50 \mu \mathrm{g} / \mathrm{mL}$ (50 ng/ $\mu \mathrm{L}$ ) (Collares et al., 2010). Keberhasilan transfer gen melalui elektroporasi sperma, terdeteksi dengan menggunakan analisis PCR dengan primer spesifik suatu gen yang disisipkan dalam vektor ekspresi (konstruksi gen yang ditransfer) (Subyakto et al., 2011). Hal ini membuktikan keberhasilan pengiriman DNA asing (transgen) untuk memasuki spermatozoa. Hasil perlakuan elektroporasi pada sperma lele mutiara dan lokal sebesar $125 \mathrm{Vcm}-1$ dengan jumlah pulsa 3; $125 \mathrm{Vcm}-1$ dengan jumlah pulsa 5; 50 Vcm-1 dengan jumlah pulsa 3 dan $50 \mathrm{Vcm}-1$ dengan jumlah pulsa 5 , menunjukkan keberhasilan transfer gen GH lele dumbo pada kedua sperma lele tersebut, yang diindikasikan dengan terdeteksinya fragmen berukuran 600 bp yang merupakan gen GH lele dumbo pada sperma lele mutiara dan lokal pasca elektroporasi (Gambar 8).

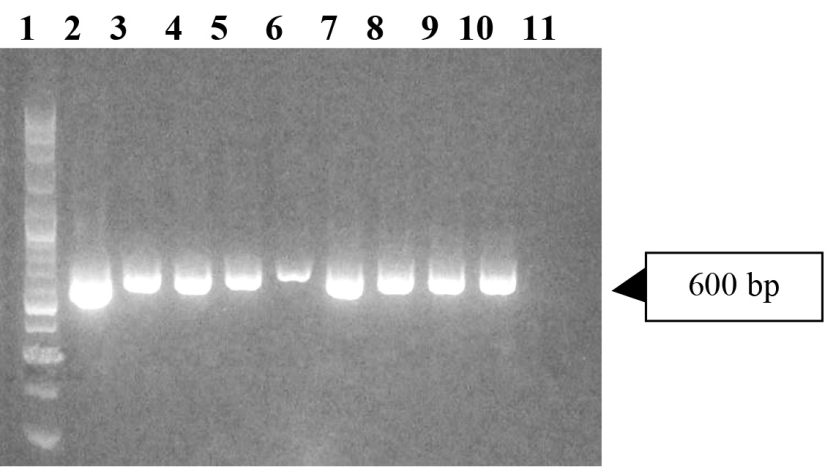

Gambar 8. Deteksi Transgen (menggunakan Primer Cg-F dan Cg-R)

Keterangan :

1 = marker VC 100 bp plus DNA ladder (Vivantis)

2 = konstruksi vektor gen hormon pertumbuhan lele dumbo (pTarget-CMV-CgGH) (kontrol positif)

3 = perlakuan elektroporasi sperma lele lokal (50 Vcm-1 - jumlah pulsa 3 kali)

4 = perlakuan elektroporasi sperma lele lokal (50 Vcm-1 - jumlah pulsa 5 kali)

5 = perlakuan elektroporasi sperma lele lokal (125 Vcm-1 - jumlah pulsa 3 kali)

6 = perlakuan elektroporasi sperma lele lokal $(125 \mathrm{Vcm}-1-$ jumlah pulsa 5 kali)

$7=$ perlakuan elektroporasi sperma lele mutiara $(50 \mathrm{Vcm}-1-$ jumlah pulsa 3 kali)

8 = perlakuan elektroporasi sperma lele mutiara $(50 \mathrm{Vcm}-1-$ jumlah pulsa 5 kali)

$9=$ perlakuan elektroporasi sperma lele mutiara (125 Vcm-1 jumlah pulsa 3 kali)

$10=$ perlakuan elektroporasi sperma lele mutiara (125 Vcm-1 jumlah pulsa 5 kali)

$11=$ kontrol negatif

\= fragmen gen hormon pertumbuhan lele dumbo (60o bp)

Berdasarkan hasil elektroforegram Gambar 8, menunjukkan bahwa sisipan gen GH lele dumbo yang ditransfer ke sperma lele mutiara terdeteksi dengan ukuran fragmen GH sekitar 600 bp yang sejajar dengan fragmen 
GH yang terkandung dalam kontrol positif (pTargetCMV-CgGH) (sumur ke-2 Gambar 8). Fragmen GH lele dumbo terdeteksi pada semua perlakuan elektroporasi, baik pada sperma lele mutiara pada kejut listrik $50 \mathrm{Vcm}-1$ dan 125 Vcm-1 serta jumlah pulsa 3 dan 5 kali. Dengan demikian pada sperma lele mutiara dan lele lokal telah tersisip gen GH lele dumbo. Keberhasilan transfer DNA asing juga ditunjukkan dari hasil penelitian Collares et al. (2010), yang menggunakan sperma lele Amerika (Rhamdia quelen), bahwa umumnya sperma ikan yang telah dielektroporasi masih mampu membuahi telur dengan derajat penetasan $70-80 \%$ sehingga embrio telur mengandung sisipan DNA asing tersebut dalam menghasilkan larva ikan transgenik. Hasil deteksi sisipan GH lele dumbo pada sperma lele mutiara dan lokal (Gambar 8), menunjukkan bahwa baik voltase maupun jumlah pulsa yang diaplikasikan dalam proses elektroporasi transfer GH lele dumbo ke sperma lele mutiara dan lokal berhasil masuk dan terintegrasi ke dalam genom sperma lele tersebut. Hasil deteksi keberadaan gen GH lele dumbo yang ditransfer ke dalam kedua sperma lele ini menunjukkan bahwa sel-sel sperma ikan lebih memungkinkan digunakan sebagai vektor untuk transfer DNA asing melalui elektroporasi. DNA asing ini (termasuk pTarget-CMV-CgGH) masuk melalui proses internalisasi DNA oleh sel-sel sperma selama perlakuan elektroporasi (Venogupal \& Pandian, 2002).

Kuat medan listrik (voltase) tinggi mempermudah pengambilan DNA asing oleh sel-sel sperma, namun voltase yang terlalu tinggi menyebabkan penurunan motilitas dan kemampuan fertilisasi sperma. Batas voltase optimum yang cukup untuk efisiensi transfer gen ke sperma ikan sebesar 500 Vcm-1. Terkait dengan perlakuan tersebut, pemberian voltase 125 dan $50 \mathrm{Vcm}-1$ pada elektroporasi sperma lele mutiara dan lokal efisien untuk transfer gen ke dalam sel sperma, dan terbukti fragmen $\mathrm{GH}$ lele dumbo terdeteksi oleh primer $\mathrm{Cg}-\mathrm{F}$ dan Cg-R (Gambar 8). Kombinasi perlakuan voltase dan jumlah pulsa dalam elektroporasi sperma memperbesar permeabilitas sel, menyebabkan polinukleotida eksogen (DNA asing) memasuki membran plasma sel sperma (Liu et al., 2011). DNA asing ini lebih lanjut dikirimkan kembali oleh sperma ke telur saat fertilisasi yang efektif untuk memproduksi ikan transgenik pembawa fenotip baru (Spadafora, 2008; Tsai, 2000). Transgen (pembawa gen GH lele dumbo) dapat ditransmisikan kembali melalui reproduksi seksual dari parental (P) ke keturunan pertama (F1) dengan ekspresi fenotip baru.

Transfer gen GH patin siam ke dalam sperma ikan lele (Clarias sp.) menggunakan kejut listrik dengan jumlah kejutan 5 kali pada tegangan $125 \mathrm{Vcm}-1$ juga berhasil dilakukan oleh Dewi et al. (2013), dan transgen terdeteksi pada ikan yang berumur 2 bulan. Hasil ini menunjukkan bahwa jumlah kejutan 5 kali memberikan peluang lebih besar transgen memasuki spermatozoa ikan. Diharapkan melalui serangkaian tahap pemeliharaan benih hingga menjadi calon induk, dapat diperoleh induk lele transgenik Fo.

\section{Profil Pertumbuhan Lele Mutiara Transgenik}

Pertumbuhan ikan dari hari ke hari (khususnya lele transgenik) menunjukkan perubahan ukuran menjadi lebih besar dibandingkan ikan lele non transgenik. Pada pemeliharaan ikan lebih lanjut, baik perlakuan elektroporasi 50 Vcm-1-jumlah pulsa 3 dan $50 \mathrm{Vcm}-1-$ jumlah pulsa 5 , pertumbuhan lele transgenik lebih besar.

Beberapa ekor ikan lele transgenik (strain mutiara) tumbuh besar dan profil pertumbuhannya di atas rata-rata ikan lain dalam bak pemeliharaan yang sama. Ikan-ikan lele yang berukuran besar ini, diduga merupakan ikan lele transgenik, oleh karena ekspresi pertumbuhannya lebih besar dibandingkan dengan pertumbuhan ikan lain. Beberapa ikan yang berukuran besar ini terlihat pada bak pemeliharaan perlakuan elektroporasi sperma $50 \mathrm{Vcm}-1$ - pulsa 3 ; $50 \mathrm{Vcm}-1$ - pulsa $5 ; 125 \mathrm{Vcm}-1$ - pulsa 3 dan 125 Vcm-1 - pulsa 5 (Gambar 9). Hal ini mengindikasikan bahwa konstruksi gen (pTargetCMV-GH lele dumbo) yang ditransformasikan ke sperma lele mutiara berhasil masuk ke sperma, kemudian transgen mendorong ekspresi hormon pertumbuhan eksogen sehingga pertumbuhan lele mutiara transgenik menjadi berlipat ganda (over-ekspresi GH eksogen) bila dibandingkan lele mutiara yang tidak membawa transgen (non elektroporasi).

Pertumbuhan yang dramatis pada ikan transgenik ini (Gambar 9) membuktikan adanya efek pertumbuhan gigantism dimana pertumbuhan ikan menjadi sangat besar dibandingkan dengan yang lain pada umur pemeliharaan yang sama. Gambar 10 (a - e) memperlihatkan pertumbuhan ikan lele mutiara transgenik pada hari ke-58, lebih besar dibandingkan pertumbuhan ikan non transgenik (ikan yang tidak membawa sisipan gen $\mathrm{GH}$ eksogen)

Respon dan nafsu makan yang tinggi pada ikan lele mutiara transgenik terhadap pakan buatan maupun pakan segar ini sebagai efek dari sisipan GH eksogen yang memacu sekresi insulin-like growth factor-I (IGF-I), suatu hormon yang disekresikan dari hati dan jaringan lainnya sebagai respon dari adanya hormon pertumbuhan (Bowen, 2006). Peningkatan sekresi IGF-I ini lebih lanjut memicu produksi hormon pertumbuhan lebih banyak, sehingga memacu pertumbuhan ikan. Kondisi ini terlihat sebaliknya pada pertumbuhan lele mutiara yang non transgenik, rata-rata ukuran ikan relatif kecil dan seragam.

Pertumbuhan ikan lele mutiara non transgenik (sperma ikan tidak dielektroporasi), menunjukkan pertumbuhan ikan lele yang normal seperti pertumbuhan ikan lele pada umumnya. Efek gigantism tidak terjadi pada ikan lele non transgenik ini (Gambar 10e), dimana pertumbuhan ikan tidak meningkat secara dramatis seperti yang dibuktikan pada ikan lele transgenik. Ekspresi pertumbuhan hanya berasal dari GH endogen yang dimiliki ikan.

Over ekspresi pertumbuhan ikan lele mutiara transgenik merupakan bukti bahwa promoter CMV mendorong ekspresi $\mathrm{GH}$ eksogen (GH lele dumbo 


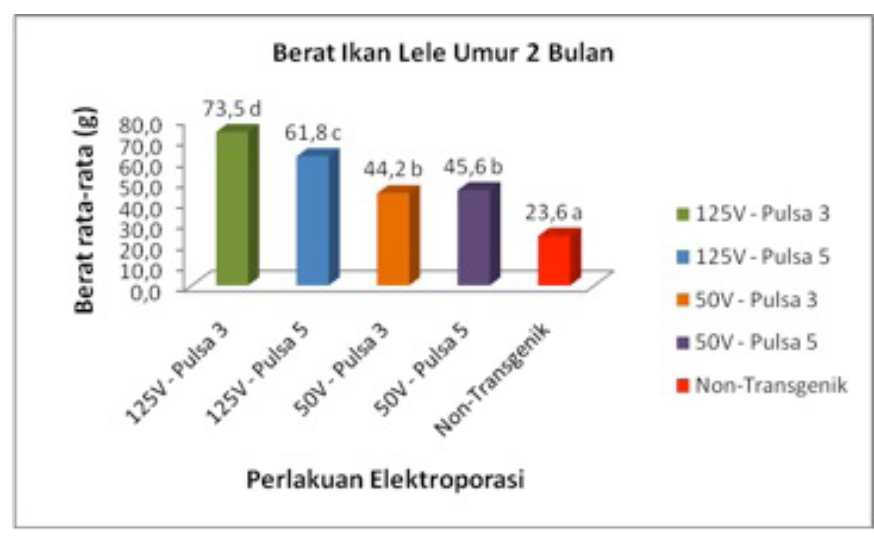

Gambar 9. Perbedaan Berat Rata-rata Ikan Lele Trasgenik (Perlakuan Elektroporasi) dan Ikan Lele Non Transgenik Berdasar Uji Jarak Berganda Duncan 95\% (Angka yang Diikuti Huruf yang Tidak Sama Menunjukkan Perbedaan Nyata).

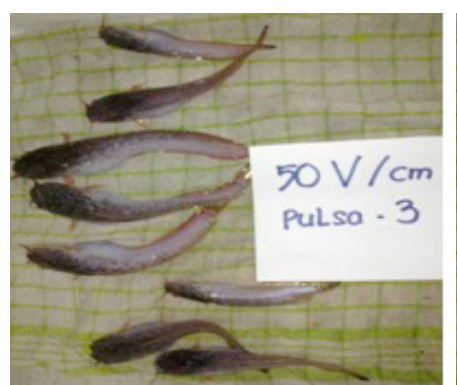

(A)

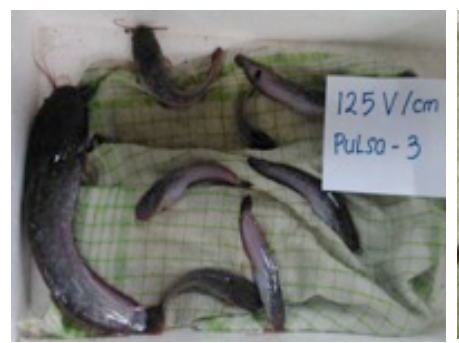

(C)

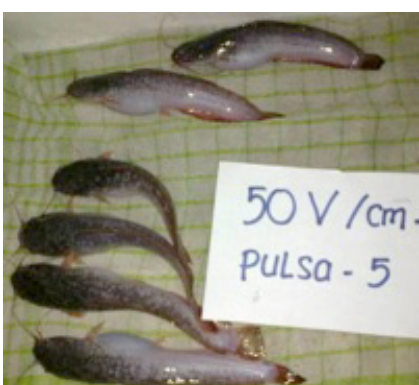

(B)

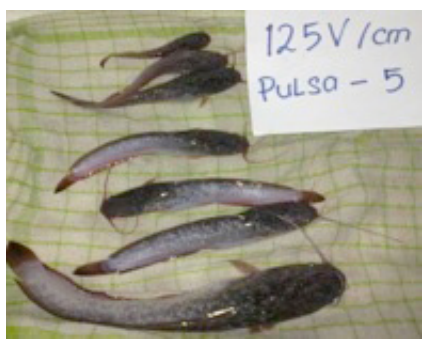

(D)

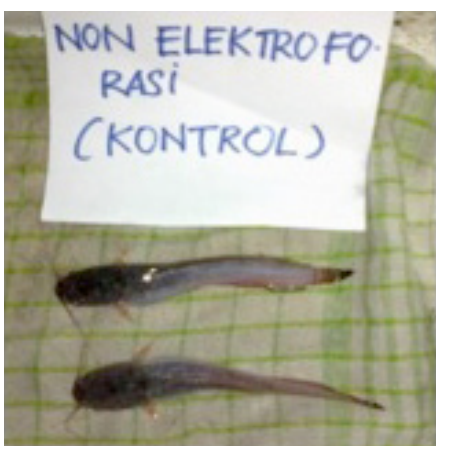

(E)

Gambar 10. Lele Mutiara Transgenik 50 Vcm-1-Pulsa 3 (a), 50 Vcm-1-Pulsa 5 (b), 125 Vcm-1-Pulsa 3, 125 Vcm1-Pulsa 5 dan NoN Elektroporasi (e) pada Hari ke-58

yang disisipkan ke dalam vektor rekombinan) menjadi pertumbuhan yang berlipat ganda dari ukuran ikan yang sama, mengingat promoter CMV merupakan promoter kuat (strong promoter). Penelitian penggunaan promoter CMV ini untuk pembuatan ikan transgenik telah banyak

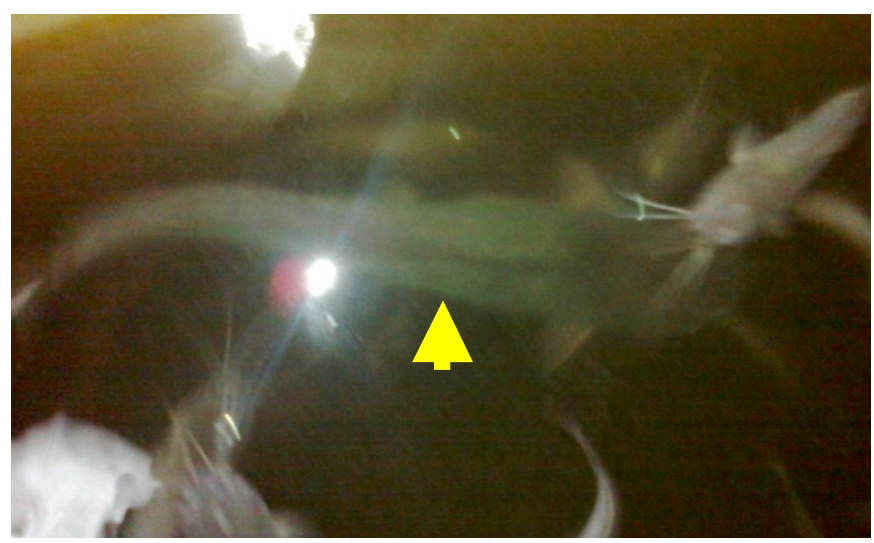

Gambar 11a. Elektroporasi 125 Vcm-1 - Pulsa 3 $\gamma=$ ikan lele mutiara transgenik

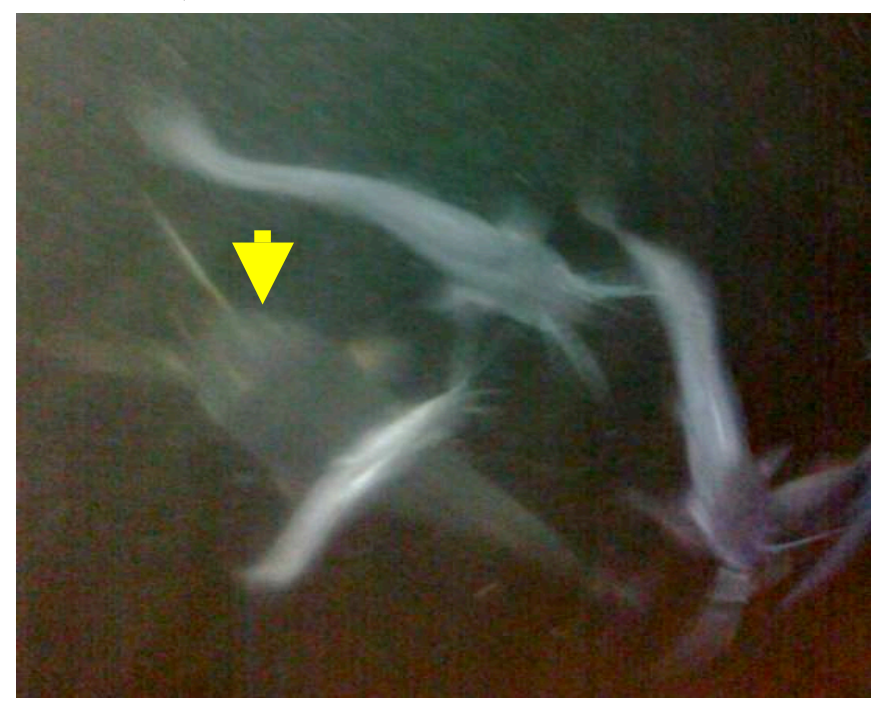

Gambar 11b.Elektroporasi $125 \mathrm{Vcm}^{-1}$ - Pulsa 5 $\gamma=$ ikan lele mutiara transgenik

dilakukan, salah satunya oleh Martinez et al. (1996), dalam pembuatan ikan tilapia transgenik-GH yang membuktikan bahwa sekuen dari promoter tersebut mampu secara langsung mendorong ekspresi GH tilapia dalam embrio dan sel-sel ikan. Performans pertumbuhan ikan tilapia transgenik menghasilkan berat rata-rata antara $220-710$ g/ekor lebih besar $82 \%$ dibandingkan dengan ikan non transgenik (rata-rata antara 96- 472 g/ekor). Hasil ini membuktikan bahwa promoter CMV pada ikan tilapia transgenik memberikan ekspresi peningkatan pertumbuhan sebesar 1,81 kali dibandingkan ikan tilapia normal (non transgenik). Hasil penelitian Dewi et al. (2012), yang menyisipkan gen GH ikan patin siam $(\mathrm{PhGH})$ dengan promoter $\beta$-aktin ikan mas (pCcBA) melalui sperma ikan patin siam (Pangasionodon hypopthalmus) menghasilkan ikan patin siam transgenikGH dengan bobot rata-rata 1,56 - 1,65 kali dibandingkan ikan non transgenik yang menunjukkan adanya overekspresi hormon pertumbuhan.

Pertumbuhan ikan lele mutiara transgenik (umur pemeliharaan hari ke-62) pada elektroporasi $125 \mathrm{Vcm}$ 1-pulsa 3 dan $125 \mathrm{Vcm}-1$-pulsa 5 kira-kira 3 kali lipat dari lele mutiara yang non transgenik (Gambar 11a dan 11b). 
Ekspresi gen hormon pertumbuhan lele dumbo yang terkandung dalam ikan lele mutiara transgenik pada Gambar 11a dan 11b mampu meningkatkan pertumbuhan ikan tersebut lebih besar dibanding ikan lele mutiara normal (non transgenik). Over ekspresi pertumbuhan ini menunjukkan bahwa baik hormon pertumbuhan lele dumbo (GH eksogen) dan hormon pertumbuhan lele mutiara (GH endogen) keduanya berperan memacu pertumbuhan pada ikan transgenik tersebut. Pertumbuhan yang dramatis pada ikan transgenik ini membuktikan adanya efek pertumbuhan gigantisme dimana pertumbuhan ikan melebihi pertumbuhan ikan lele non transgenik pada umur pemeliharaan yang sama. Pada Tabel 1 di bawah disajikan hasil pertumbuhan ikan lele mutiara transgenik pada umur 4 bulan sebesar 2-3 kali dari pertumbuhan ikan non transgenik (ikan yang tidak membawa gen GH lele dumbo). Hasil pengukuran berat ikan lele transgenik khususnya ikan yang besar menunjukkan rata-rata pertumbuhan ikan lele transgenik 2- 3 kali pertumbuhan ikan lele non transgenik (Gambar 12).

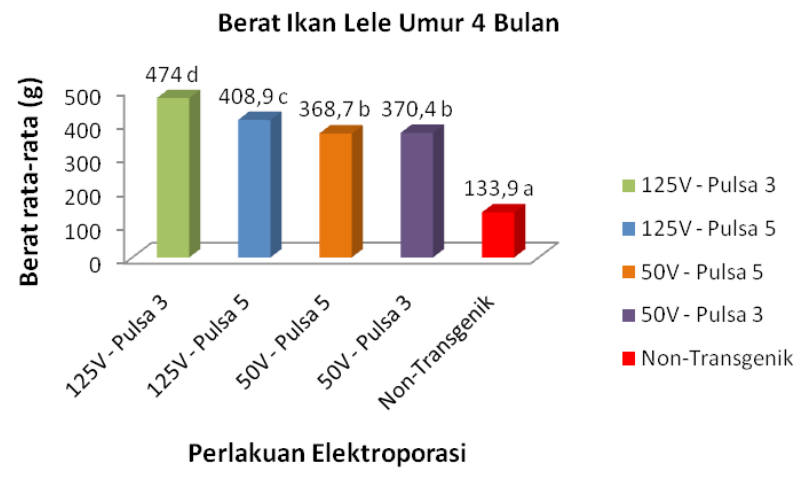

Gambar 12. Perbedaan berat Rata-rata Ikan Lele Trasgenik (Perlakuan Elektroporasi) dan Ikan Lele Non Transgenik Berdasar Uji Jarak Berganda Duncan 95\% (Angka yang Diikuti Huruf yang Tidak Sama Menunjukkan Perbedaan Nyata).

Keterangan :

$125 \mathrm{~V}-3$ = elektroporasi $125 \mathrm{Vcm}-1$ dengan jumlah pulsa 3 $125 \mathrm{~V}-5$ = elektroporasi $125 \mathrm{Vcm}-1$ dengan jumlah pulsa 5 $50 \mathrm{~V}-3=$ elektroporasi $50 \mathrm{Vcm}-1$ dengan jumlah pulsa 3 $50 \mathrm{~V}-5$ = elektroporasi $125 \mathrm{Vcm}-1$ dengan jumlah pulsa 5

Ukuran berat rata-rata ikan pada hasil elektroporasi $125 \mathrm{Vcm}-1$ dan $50 \mathrm{Vcm}-1$ dengan jumlah pulsa 3 dan 5 (ikan transgenik) masing-masing 474 g, 408,9 g, 368,7 g dan 370,4 g (Gambar 12). Kelipatan tumbuh rata-rata sampel lele transgenik terhadap ikan lele non transgenik sebesar 3,53 kali; 3,05 kali; 2,75 kali dan 2,76 kali. Bukti ini menunjukkan bahwa konstruksi gen (pTarget-CMV$\mathrm{CgGH}$ ) yang mengandung $\mathrm{GH}$ lele dumbo dan disisipkan ke ikan lele mutiara menghasilkan ikan transgenik dengan pertumbuhan berlipat (super growth) dibanding ikan non transgenik. Hasil penelitian transfer gen GH patin siam dalam konstruksi gen pCcBA-PhGH ke dalam sperma patin melalui teknik elektroporasi, menunjukkan bahwa tingkat transmisi gen tersebut dari generasi Fo (parental) ke generasi F1 sebesar 66,7 \% dan selama 4 bulan pemeliharaan, populasi F1 patin transgenik tumbuh 47,5\% lebih cepat dibanding ikan patin non transgenik (Dewi dkk., 2014). Penelitian lain juga membuktikan over ekspresi pertumbuhan ikan Atlantic salmon (Salmo salar) transgenik memiliki kelipatan tumbuh sebesar 2,85 kali dari ikan non transgenik (Cook et al., 2000). Dengan demikian hal ini memperkuat bukti bahwa efek gigantism dari pertumbuhan ikan lele mutiara transgenik merupakan over ekspresi GH lele dumbo sebagai ekspresi fenotip baru ikan lele transgenik.

Keberadaan GH lele dumbo pada ikan lele mutiara transgenik (elektroporasi $125 \mathrm{Vcm}-1$ - pulsa $3,125 \mathrm{Vcm}$ 1 - pulsa $5,50 \mathrm{Vcm}-1$ - pulsa 3 dan $50 \mathrm{Vcm}-1$ - pulsa 5 ) berhasil dideteksi menggunakan primer $\mathrm{Cg}-\mathrm{F}$ dan $\mathrm{Cg}-\mathrm{R}$ (Gambar 7), sebaliknya sisipan hormon pertumbuhan lele dumbo tidak terdapat pada ikan non transgenik. Terdapat 4 - 7 fragmen DNA yang terkopi dalam ikan transgenik, sedangkan pada ikan non transgenik (NT) hanya 1 fragmen DNA (Gambar 7). Untuk memastikan fragmenfragmen DNA yang terkopi merupakan gen penyandi GH lele dumbo diperlukan sekuensing, dan hasilnya menunjukkan bahwa fragmen DNA berukuran $1000 \mathrm{bp}$ (Tabel 1) merupakan sekuen gen hormon pertumbuhan lele dumbo, sedangkan fragmen yang berukuran $375 \mathrm{bp}$ bukan merupakan sekuen gen GH lele dumbo.

Tabel 1. Penyejajaran Sekuen GH Sampel dengan GH bankgen (Program Blast on-line)

\begin{tabular}{|c|c|c|c|}
\hline $\begin{array}{l}\text { Elektroporasi } \\
\text { (kode sampel) }\end{array}$ & Sekuen GH & $\begin{array}{c}\% \\
\text { identik }\end{array}$ & No. aksesi \\
\hline $125 \mathrm{~V} / \mathrm{cm}-3-1000 \mathrm{bp}(1)$ & $\begin{array}{l}\text { Gen protein } G H C . \\
\text { gariepinus }\end{array}$ & 96 & AF416488.1 \\
\hline $125 \mathrm{~V} / \mathrm{cm}-3-1000 \mathrm{bp}(2)$ & $\begin{array}{l}\text { Gen protein } G H C \text {. } \\
\text { gariepinus }\end{array}$ & 96 & AF416488.1 \\
\hline $125 \mathrm{~V} / \mathrm{cm}-3-1000 \mathrm{bp}(3)$ & $\begin{array}{l}\text { Gen protein } G H C \text {. } \\
\text { gariepinus }\end{array}$ & 99 & AF416488.1 \\
\hline $125 \mathrm{~V} / \mathrm{cm}-5-1000 \mathrm{bp}(4)$ & $\begin{array}{l}\text { Gen protein } G H C \text {. } \\
\text { gariepinus }\end{array}$ & 98 & AF416488.1 \\
\hline $125 \mathrm{~V} / \mathrm{cm}-5-1000 \mathrm{bp}(5)$ & $\begin{array}{l}\text { Gen protein } G H C \text {. } \\
\text { gariepinus }\end{array}$ & 94 & AF416488.1 \\
\hline $50 \mathrm{o} / \mathrm{cm}-3-1000 \mathrm{bp}(6)$ & $\begin{array}{l}\text { Gen protein GH C. } \\
\text { gariepinus }\end{array}$ & 95 & AF416488.1 \\
\hline $50 \mathrm{~V} / \mathrm{cm}-5-1000 \mathrm{bp}(7)$ & $\begin{array}{l}\text { Gen protein GH } C \text {. } \\
\text { gariepinus }\end{array}$ & 95 & AF416488.1 \\
\hline NT-375 bp (8) & $\begin{array}{l}\text { Clarias batrachus } \\
\text { mitochondrion, } \\
\text { complete genome }\end{array}$ & 35 & $\begin{array}{l}\text { KC572134.1 } \\
\text { (bukan GH } \\
\text { lele dumbo) }\end{array}$ \\
\hline
\end{tabular}

Hasil penyejajaran sekuen sampel (fragmen DNA berukuran $1000 \mathrm{bp}$ ) dengan urutan nukleotida pada bankgen (aplikasi program blast on-line) diperoleh kesamaan tinggi (94 - 98\%) untuk gen penyandi hormon pertumbuhan lele dumbo (Clarias gariepinus) sehingga kopi fragmen DNA berukuran 1000 bp tersebut yang terdapat pada genom sampel lele mutiara transgenik merupakan GH eksogen (GH lele dumbo) yang ditransfer ke lele mutiara (Tabel 1 serta Gambar 13a dan 13b). 


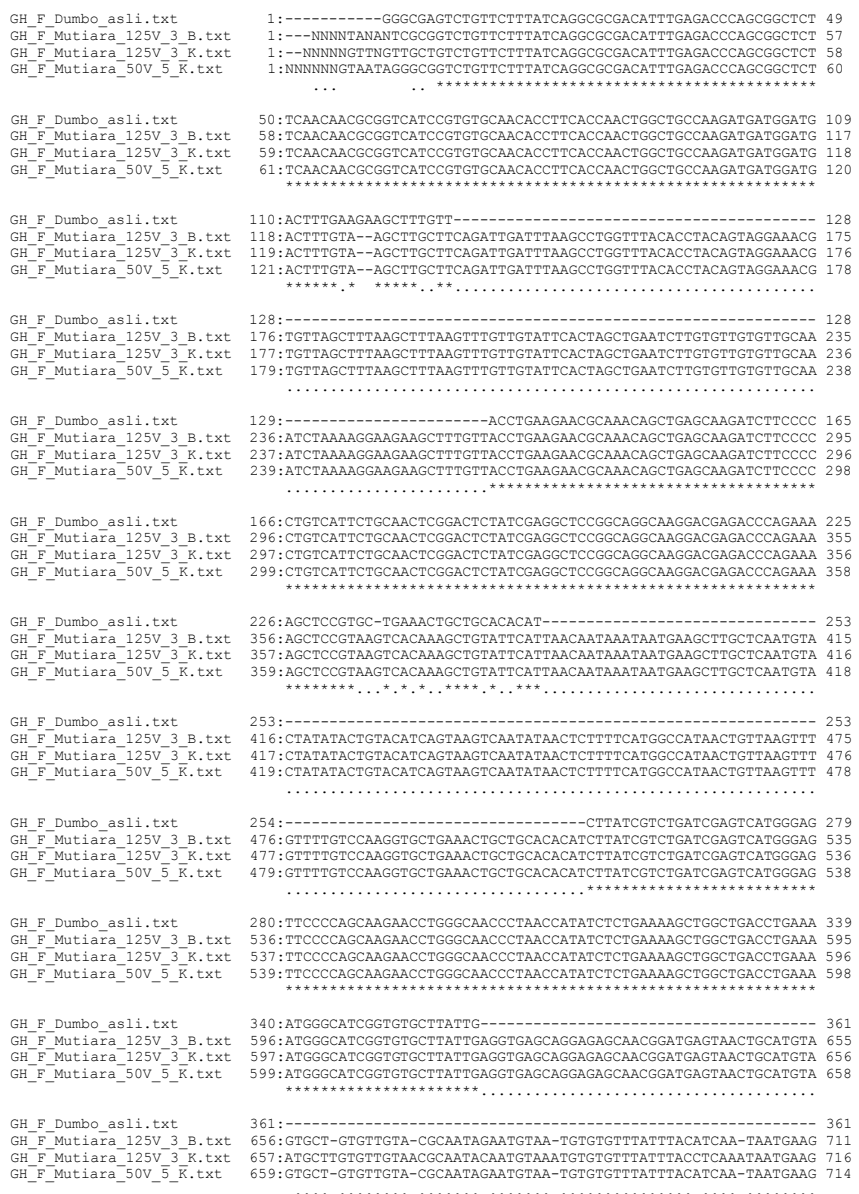

Gambar 13a. Penyejajaran Sekuen Arah Forward GH Sampel (GH Lele Dumbo, GH Lele Mutiara Transgenik) dengan GH Bankgen (Program Genetyx versi 7.0)

keterangan $:{ }^{*}=$ menunjukkan sekuen nukleotida yang sama

Kemiripan sekuen GH sampel (Gambar 13a dan 13b) dengan gen protein GH C. gariepinus pada bankgen (no. aksesi AF416488.1) membuktikan bahwa GH eksogen tersisip dalam genom ikan lele mutiara. Dengan demikian ikan lele transgenik (selain mengandung GH endogen, juga mengandung GH eksogen yang berasal dari lele dumbo) telah berhasil diperoleh. Sebaliknya pada genom lele mutiara non elektroporasi (NT), tidak terdeteksi keberadaan fragmen berukuran 1000 bp (yang merupakan fragmen GH lele dumbo), yang menunjukkan bahwa ikan lele ini memang bukan ikan lele mutiara transgenik (non transgenik), diindikasikan dengan tidak adanya fragmen GH eksogen berukuran 1000 bp yang terdeteksi. Pada ikan lele mutiara non transgenik ini hanya terkopi fragmen berukuran 375 bp yang mirip dengan gen penyandi Sox9a C. batrachus (no. aksesi KJ784470.1) atau gen penyandi mitokondria C. batrachus (no. aksesi KC572134.1). Berdasar hasil tersebut terbukti bahwa promoter CMV merupakan promoter kuat yang dapat mendorong ekspresi gen $\mathrm{GH}$ sehingga menimbulkan over-ekspresi dan memberikan peningkatan pertumbuhan berlipat dibandingkan ikan yang normal, seperti yang terlihat dalam penelitian ini.

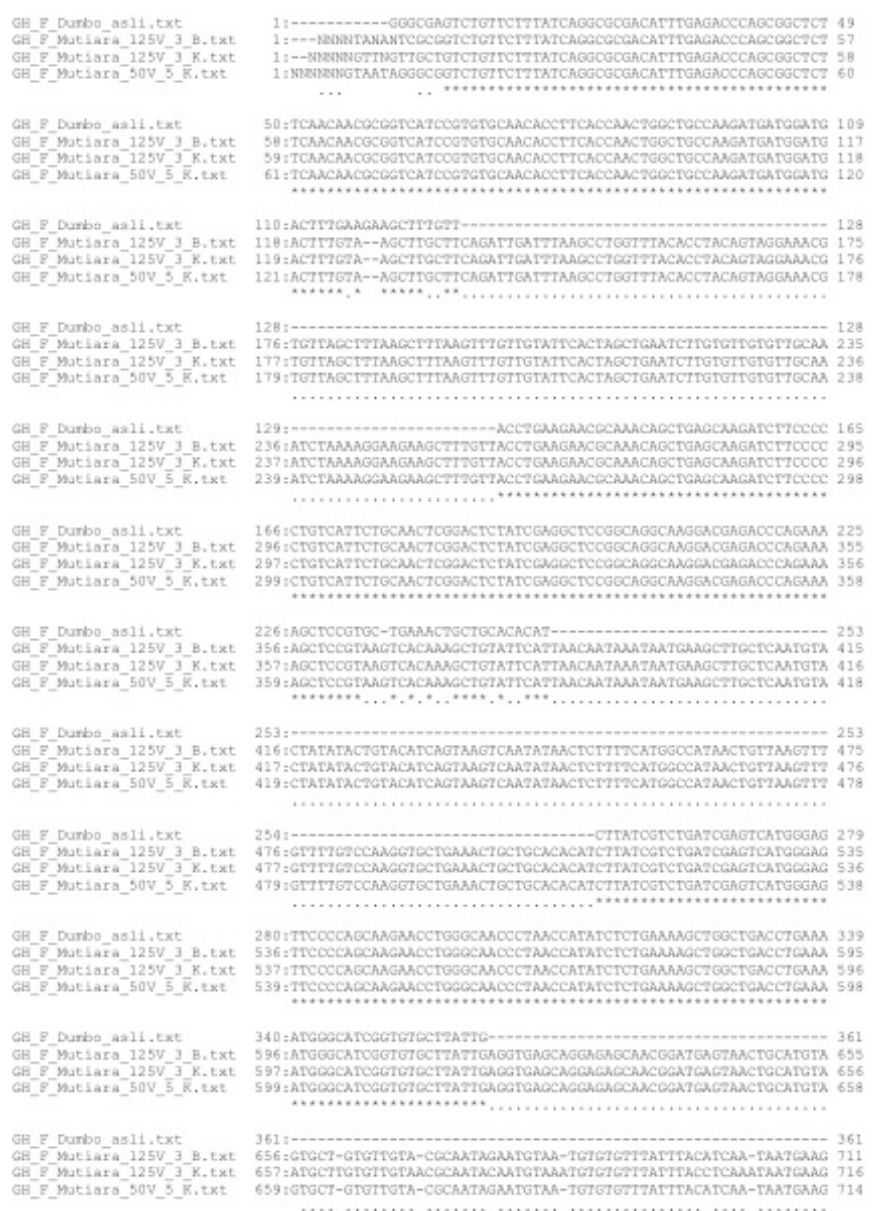

Gambar 13b. Penyejajaran Sekuen Arah Reverse GH Sampel (GH Lele Dumbo, GH Lele Mutiara Transgenik) dengan GH Bankgen (Program Genetyx versi 7.0)

keterangan $:{ }^{*}=$ menunjukkan sekuen nukleotida yang sama

\section{SIMPULAN}

Berdasarkan hasil yang dicapai selama kegiatan pengerjaan penelitian di laboratorium, dapat disimpulkan bahwa sisipan (insert) gen hormon pertumbuhan lele dumbo dari hasil transformasi pTarget-CMV-GH lele dumbo ke dalam sel kompeten dapat dideteksi dengan primer $\mathrm{Cg}-\mathrm{GH}-\mathrm{F}$ dan $\mathrm{Cg}-\mathrm{GH}-\mathrm{R}$. Transfer gen hormon pertumbuhan lele dumbo ( $\mathrm{GH}$ eksogen) berhasil dimasukkan ke dalam sperma lele mutiara melalui elektroporasi $50 \mathrm{~V} \mathrm{~cm}-1$ dan $125 \mathrm{~V} \mathrm{~cm}-1$ dengan jumlah pulsa 3 dan 5 serta terdeteksi pada fragmen berukuran 1000 bp (96\% identik dengan GH C. gariepinus) dengan no. aksesi bankgen AF416488.1 pada ikan umur 4 bulan. Rata-rata kelipatan tumbuh ikan lele mutiara transgenik hasil elektroporasi $125 \mathrm{Vcm}-1$ - pulsa 3, $125 \mathrm{Vcm}-1$ pulsa $5,50 \mathrm{Vcm}-1$ - pulsa 3 dan $50 \mathrm{Vcm}-1$ - pulsa 5 berturut-turut 3,53 kali; 3,05 kali; 2,75 kali dan 2,76 kali dari ukuran ikan non transgenik.

\section{SARAN}

Penelitian lebih lanjut yang diperlukan adalah persilangan ikan lele mutiara transgenik Fo dengan ikan 
lele normal guna stabilisasi pewarisan GH lele dumbo pada keturunan F1 sebelum diproduksi massal untuk usaha budidaya lele di masyarakat.

\section{KEPUSTAKAAN}

Alimuddin, W. Nugrahani, R.S. Aliah, K. Sumantadinata, I. Faizal, O. Carman dan G.Yoshizaki. 2007. Isolasi dan karakterisasi promoter B-actin dari ikan kerapu bebek (Cromileptes altivelis). J. Riset Akuakultur 2(2):199-209.

Bowen, R. 2006. Growth Hormone (Somatotropin). http://www. vivo.colostate.edu/hbooks/pathphys/endocrine/hypopit/ gh.html

Caelers, A., N. Maclean, G. Hwang, E. Eppler, M. Reinecke. 2005. Expression of endogenous and exogenous growth hormone (GH) messenger (m) RNA in a GH-transgenic tilapia (Oreochromis niloticus). Transgenic Research 14:95-104.

Collares, T., V.F. Campos, F.K. Seixas, P.V. Cavalcanti, O.A. Dellagostin, H.L.M. Moreira, J.C. Deschamps. 2010. Transgene Transmission in South American Catfish (Rhamdia quelen) Larvae by Sperm-Mediated Gene Transfer. J. Biosci. 35(1):1-9.

Cook, J.T., M.A. McNiven, G.F. Richardson, and A.M. Sutterlin. 2000. Growth rate, body composition and feed digestibility / conversion of growth-enhanced transgenic Atlantic salmon (Salmo salar). Aquaculture 188:15-32.

Dewi, R.R.S.P.S, Alimuddin, A.O. Sudradjat, K. Sumantadinata. 2010b. Efektivitas Transfer dan Ekspresi Gen PhGH Pada Ikan Patin Siam (Pangasionodon hypophthalamus). Laporan Akhir Hasil Penelitian 2010. LRPTBPAT Sukamandi.

Dewi, R.R.S.P.S., Alimuddin, A.O Sudrajat dan K. Sumantadinata. 2012. Efektivitas transfer dan ekspresi gen $\mathrm{PhGH}$ pada ikan patin siam (Pangasionodon hypopthalmus). J. Riset Akuakultur 7(2):171-180.

, H. Marnis, R. Suprapto, dan N. Syawalia. 2013. Produksi ikan lele cepat tumbuh generasi F-o menggunakan metode transgenesis. J.Riset Akuakultur 8(2):173 $-180$.

Dewi, R.R.S.P.S., J. Darmawan, dan I. Nurlaela. 2014. Transmisi dan ekspresi fenotipe gen penyandi hormon pertumbuhan pada ikan patin siam. J. Ris. Akuakultur 9(1):31-37.

Faqih, A. R. 2011. Penurunan motilitas dan daya fertilisasi sperma ikan lele dumbo (Clarias sp.) pasca perlakuan stress kejutan listrik. J.Exp. Life Sci., 1 (2) : $72-82$.

Fletcher, G.L., M.A. Shears, M.J. King, S.V. Goddard. 2002. Transgenic salmon for culture and consumption.[Online], Available: "http://www.heb.pac.dfomp.gc.ca/congress/2002/ biochem/fletcher.pdf".[26 April 2012].

Gusrina, Alimuddin, K. Sumantadinata, U. Widyastuti. 2009. Transfer Gen Penyandi Hormon Pertumbuhan Ikan Nila (tiGH) Pada Ikan Lele (Clarias sp.) dengan Metode Mikroinjeksi. J. Riset Akuakultur 4(3):333-340.

Hackett, P.B. 1993. The molecular biology of transgenic fish. In: Hochacha and Mommessen (Eds). Biochemistry and molecular biology of fishes I(2):218- 221.
Iyengar, A., and N. Maclean. 1995. Transgene cncatemerisation and expression in rainbouw trout. Mol. Mar.Biol.Biotech.,4: 248-254.

Martinez, R., M.P. Estrada, J. Berlanga, I. Guillen, O. Hernandez, E.Cabrera, R. Morales, A. Morales, P. Melamed, R. Leionart, and $\mathrm{J}$ de la Fuente. 1996. Growth enhancement in transgenic tilapia by ectopic expression of tilapia growth hormone. Mol. Mar.Biol. Biotech.5(1):62-70.

Muller, F., L. Zsolt, V. Laszio, M. Lazsio and O. Laszio. 1993. Efficient transient expression system based on square pulse electroporation and in vivo luciferase assay of fertilized fish eggs. Federation of European Biochemical Societies 324(1):27-32.

Nam, Y.K., J.K. Noh, Y.S. Cho, H.J. Cho, K.N. Cho, C.G. Kim and D.S. Kim. 2001. Dramatically accelerated growth and extraordinary gigantism of transgenic mud loach Misgurnus mizolepiz. Transgenic Res.10:353-362.

Noh, J.K., K.N. Cho, E.H. Han, A. Kim, J.S. Lee, D.S. Kim and C. B. Kim. 2003. Genomic cloning of mud loach Misgurnus mizolepis (Cyprinids, Cobiitidae) beta actin gene and usefulness of its promoter region for fish transgenesis. Mar. Biotechnol.5(3):244-252.

Pandian, T.J., and T. Venogupal. 2005. Contribution to transgenesis in Indian major carps Labaeo rohita. In: Fish Genetics and Aquaculture Biotechnology (ed.by T.J. Pandian; C.A. Strussman and M.P. Marian). Science Publishers, Inc., USA. Hlm. 1-20.

Powers, D.A., T.T. Chen, and R.A.Dunham. 1992. Transgenic fish : in Transgenesis : Applications of gene transfer (ed.) J.A.H. Murray (Chichester : John Wiley) pp.233-249.

Promega. 2008. Promega Product Guide 2008 (www.promega. com).

Spadafora, C., and R. Lorenzini. 2008. Sperm-Mediated Transgenesis: Practical Implications of a Biological Process. Graft 4:68-71.

Subyakto, S., Alimuddin, Rustidja, M.S. Jati, I. Faizal, R.S. Aliah, G. Astutik and K.

Sumantadinata. 2011. Comparison of three different techniques of gene transfer in humpback grouper (Cromileptes altivelis). Biotropia 18(1):13-23.

Tsai, H.J., M.H. Hsih, and J.C. Kuo. 1997. Escherichia coli-produced growth hormone as feed additive to enhance the growth of juvenile black seabream. J. Appl. Ichthyol 13: 79-82.

Tsai, H. J. 2000. Electrophorated sperm mediation of gene transfer system for finfish and shellfish. Molecular reproduction and development 56:281-284.

Venogupal, T., S. Mathavan and T.J. Pandian. 2002. Molecular cloning of growth hormone encoding cDNA Indian major carps by a modified rapid amplification of cDNA ends strategy. J.Biosci., $27: 261-272$.

Zhang, P. Hayat, M. Joice, C. Gonzalez-Villasenor, R. A. Dunham, R. A.Chen, T.T., \& Powers, D.A. 1990. Gene transfer, expression and inheritance og pRCV-rainbow trout-GHcDNA in the common carp Cyprinus carpio. Mol. Repro. Dev., 25 : 13 - 25. 